\title{
Water mediated eco-friendly green protocol for one-pot synthesis of $\alpha$-aminophosphonates at ambient conditions
}

\author{
SANTHOSH REDDY MANDHA, MANJULA ALLA* and VITTAL RAO BOMMENA \\ Crop Protection Chemicals, CSIR-Indian Institute of Chemical Technology, Tarnaka, \\ Hyderabad 500 607, India \\ e-mail: manjula@iict.res.in
}

MS received 19 June 2013; revised 30 December 2013; accepted 31 December 2013

\begin{abstract}
Increasing environmental awareness and economic concerns have led to the consideration of highly efficient one-pot, three-component, green approaches for important organic synthons. We describe here a simple, elegant and high yielding protocol for the synthesis of $\alpha$-aminophosphonates in totally solvent-free, catalyst-free conditions by reacting aldehydes, amines and trimethyl phosphite at ambient temperature.
\end{abstract}

Keywords. $\quad \alpha$-Aminophosphonates; aldehydes; amines; trimethyl phosphite; solvent-free.

\section{Introduction}

Design and development of products and processes that minimize the usage as well as generation of toxic substances have been the aim of green chemistry. Avoiding addition of supplementary chemicals, such as solvents, catalysts, promoters, etc. either in the reaction sequence or work-up process constitutes a significant step in accomplishing environmentally friendly reaction protocol. Further, designing synthetic methods at ambient temperature and pressure goes a long way in making the reaction totally clean, hazard-free and energy efficient. In continuation of our interest in developing environmentally benign efficient solvent-free protocols for the synthesis of important products, we describe here a simple, elegant and high yielding protocol for the synthesis of $\alpha$-aminophosphonates in totally solvent-free, catalyst-free conditions at ambient temperature.

Organophosphorus compounds due to their high degree of biological and pharmacological spectrum have become the subject of immense interest in recent years. ${ }^{1}$ Phosphorus analogues of the amino acids in which the carboxylic acid group is replaced by a phosphonate group have attracted particular interest in the preparation of isosteric analogues of numerous natural products. ${ }^{2}$ Their utility as antagonists in the metabolism of amino acids as enzyme inhibitors and as pharmacological agents such as antibiotics, antiviral, etc. and many other applications are well-documented. ${ }^{3}$ Thus,

*For correspondence an efficient synthesis of these organophosphorus compounds is of great interest in recent times. A number of synthetic methods have been developed during the past two decades for the preparation of $\alpha$ aminophosphonates through one-pot multicomponent reactions (MCRs).

Of all the reported methods, nucleophilic addition of dimethyl phosphite or trimethyl phosphite to imines (generated in situ from aldehydes and amines) catalysed by an acid, has emerged as an important method for the synthesis of $\alpha$-aminophosphonates. One-pot synthesis of $\alpha$-aminophosphonates directly from aldehyde, amine, and phosphite was first achieved with lanthanide triflate $^{4}$ as catalyst. Subsequently, many methods using different catalytic systems such as $\mathrm{SnCl}_{4},{ }^{5} \mathrm{BF}_{3} . \mathrm{OEt}_{2},{ }^{6} \mathrm{MgBr}_{2},{ }^{7} \mathrm{InCl}_{3},{ }^{8} \mathrm{TaCl}_{5}-\mathrm{SiO}_{2},{ }^{9}$ $\mathrm{ZrCl}_{4},{ }^{10} \mathrm{Sc}(\mathrm{DS})_{3},{ }^{11} \mathrm{H}_{3} \mathrm{PW}_{12} \mathrm{O}_{40},{ }^{12} \mathrm{BiNO}_{3} .5 \mathrm{H}_{2} \mathrm{O},{ }^{13} \mathrm{Mg}$ $\left(\mathrm{ClO}_{4}\right)_{2},{ }^{14} \beta$-cyclodextrin, ${ }^{15} \mathrm{AlCl}_{3},{ }^{16}$ amberlyst- $15,{ }^{17}$ TFA, ${ }^{18}$ sulphamic acid, ${ }^{19} \mathrm{SbCl}_{3} / \mathrm{Al}_{2} \mathrm{O}_{3},{ }^{20} \quad \mathrm{TiO}_{2},{ }^{21}$ $\mathrm{Al}_{2} \mathrm{O}_{3}-\mathrm{MW},{ }^{22} \quad \mathrm{ZrOCl}_{2} \cdot 8 \mathrm{H}_{2} \mathrm{O},{ }^{23} \mathrm{ZrO}\left(\mathrm{ClO}_{4}\right)_{2} \cdot 6 \mathrm{H}_{2} \mathrm{O},{ }^{24}$ $\mathrm{SmI}_{2},{ }^{25} \mathrm{LiClO}_{4},{ }^{26}$ Oxalic acid, ${ }^{27}$ ionic liquid, ${ }^{28}$ $\mathrm{FeCl}_{3},{ }^{29}$ silica sulphuric acid, ${ }^{30} \mathrm{CSA},{ }^{31}$ (Bromodimethyl)sulphonium bromide, ${ }^{32} \mathrm{H}_{3} \mathrm{BO}_{3},{ }^{33} \mathrm{Bi}(\mathrm{OTf})_{3},{ }^{34}$ $\mathrm{NaHSO}_{4}-\mathrm{SiO}_{2},{ }^{35}$ Yttria-zirconia, ${ }^{36} \mathrm{HClO}_{4}-\mathrm{SiO}_{2},{ }^{37}$ and microwave ${ }^{38}$ have been reported. Earlier Ranu et $a l^{39}$ reported the similar reaction under solventfree conditions at higher temperature wherein the diethylphosphite is used as a nucleophile. Many of the reported methods have limitations that include use of organic solvents, expensive catalysts, harsh reaction conditions and low yields. Though few of the reported Lewis acids are less expensive and readily available, their efficiency is low owing to the fact that they are 
either deactivated or decomposed by the presence of amines and/or water generated in situ during imine formation. ${ }^{40}$ In order to overcome such limitations, there is a need for an efficient and convenient method for construction of such significant scaffolds. Most of the reported procedures claim only trace amount of products in a solvent less neat conditions at ambient temperature. To the best of our knowledge, this is the report where in the water generated in situ catalyses the synthesis of $\alpha$-aminophosphonates in a solvent-free, and catalyst-free environment at ambient conditions.

\section{Experimental}

\subsection{Materials, methods and instruments}

All the chemicals used were of synthetic grade obtained. Analytical thin-layer chromatography (TLC) using E-Merck $0.25 \mathrm{~mm}$ silica gel plates monitored completion of the reactions time to time. Visualization was accomplished with UV light $(256 \mathrm{~nm})$ and iodine. Melting points were determined on Fisher John's and are uncorrected. All the ${ }^{1} \mathrm{H}-\mathrm{NMR}$ spectra are recorded on AVANCE $300 \mathrm{MHz}$ in $\mathrm{CDCl}_{3}$. Chemical shifts reported are on the $\delta$-scale relative to TMS internal standard. The IR spectra recorded on SHIMADZU FT-IR SPECTROPHOTOMETER using $1 \%$ potassium bromide discs. Mass spectra recorded on Waters quadruple mass spectrometry.

\subsection{General procedure for preparation of $\alpha$-aminophosphonates}

A mixture of aldehyde $(1 \mathrm{mmol})$ and amine $(1 \mathrm{mmol})$ was stirred at room temperature for $2 \mathrm{~min}$ and then trimethyl phosphite $(1 \mathrm{mmol})$ was added. After completion of the reaction, as indicated by TLC, the reaction mixture was diluted with water (in case of solid products) and the products were separated by filtration and dried. The products obtained were pure enough for all practical purposes.

\subsection{Spectral data of unreported compounds}

\section{3a Dimethyl(phenethylamino)(phenyl)}

methylphosphonate (table 1, entry 12): Pale yellow solid, m.p. $217-219^{\circ} \mathrm{C}$; IR (neat): 3384, 3036, 1524, $763 \mathrm{~cm}^{-1} ;{ }^{1} \mathrm{H}$ NMR $\left(300 \mathrm{MHz}, \mathrm{CDCl}_{3}\right): \delta 2.40$ (brs, $\mathrm{NH}), 2.65-2.81(\mathrm{~m}, 4 \mathrm{H}), 3.46(\mathrm{~d}, 3 \mathrm{H} J=10.57 \mathrm{~Hz})$, $3.66(\mathrm{~d}, 3 \mathrm{H}, J=10.57 \mathrm{~Hz}), 3.99(\mathrm{~d}, 1 \mathrm{H}, J=$ $20.39 \mathrm{~Hz}), 7.06-7.31(\mathrm{~m}, 10 \mathrm{H}) ;{ }^{13} \mathrm{C}$ NMR $(75 \mathrm{MHz}$, $\left.\mathrm{CDCl}_{3}\right): \delta 36.04,48.94\left(\mathrm{~d}, J_{\mathrm{CP}}=17.01 \mathrm{~Hz}\right), 53.24$ $\left(\mathrm{d}, J_{\mathrm{CP}}=6.58 \mathrm{~Hz}\right), 59.55,61.57,126.03,127.88$, $128.25, \quad 128.49, \quad 129.33, \quad 135.45,137.43,139.54$; MS (ESI): $m / z=320[\mathrm{M}+\mathrm{H}]^{+}$; Anal. Calcd for $\mathrm{C}_{17} \mathrm{H}_{22} \mathrm{NO}_{3} \mathrm{P}: \mathrm{C}, 63.94 ; \mathrm{H}, 6.94 ; \mathrm{N}, 4.39$. Found: $\mathrm{C}$, 64.00; H, 6.90; N, 4.45 .

\section{3b Dimethyl(phenylamino)(4-\{3,5,6-trichloro-}

pyridin-2-yloxy\}phenyl)methylphosphonate (table 1, entry 13): White solid, m.p. $165-167^{\circ} \mathrm{C}$; IR (KBr): 3327, 1602, 1412, 1236, $1036 \mathrm{~cm}^{-1} ;{ }^{1} \mathrm{H}$ NMR $\left(300 \mathrm{MHz}, \mathrm{CDCl}_{3}\right): \delta 3.46(\mathrm{~d}, J=10.57 \mathrm{~Hz}, 3 \mathrm{H}), 3.76$ $(\mathrm{d}, 3 \mathrm{H}, J=10.57 \mathrm{~Hz}), 4.72-4.83(\mathrm{~m}, 2 \mathrm{H}), 6.57(\mathrm{~d}, 2 \mathrm{H}$, $J=7.55 \mathrm{~Hz}), 6.68\left(\mathrm{t}, 1 \mathrm{H}, J_{12}=7.55 \mathrm{~Hz}\right), 7.04-7.16$ (m, 4H), 7.49-7.55 (m, 2H), $7.81(\mathrm{~s}, 1 \mathrm{H}) ;{ }^{13} \mathrm{C} \mathrm{NMR}$ $\left(75 \mathrm{MHz}, \mathrm{CDCl}_{3}\right): \delta 53.79\left(\mathrm{~d}, J_{\mathrm{CP}}=6.58 \mathrm{~Hz}\right), 54.05(\mathrm{~d}$, $\left.J_{\mathrm{CP}}=8.78 \mathrm{~Hz}\right), 54.17,56.18,113.81,117.85,118.61$, $121.46,128.96,129.20,132.75,140.72,143.48$, 144.56, 145.78, 152.65, 155.96; MS (ESI): $m / z=509$ $[\mathrm{M}+\mathrm{Na}]^{+}$; Anal. Calcd for $\mathrm{C}_{20} \mathrm{H}_{18} \mathrm{Cl}_{3} \mathrm{~N}_{2} \mathrm{O}_{4} \mathrm{P}: \mathrm{C}, 49.25$; H, 3.72; N, 5.74. Found: C, 49.45; H, 3.68; N, 5.79.

2.3c Dimethyl(phenylamino)(heptyl)methylphosphonate (table 1, entry 14): Yellow viscous liquid; IR (neat): 3310, 1607, 1478, $1025 \mathrm{~cm}^{-1}$; ${ }^{1} \mathrm{H}$ NMR $(300 \mathrm{MHz}$, $\left.\mathrm{CDCl}_{3}\right): \delta 0.86(\mathrm{t}, 3 \mathrm{H}, J=6.98 \mathrm{~Hz}), 1.21-1.73(\mathrm{~m}$, $10 \mathrm{H}), 1.79-1.93(\mathrm{~m}, 1 \mathrm{H}), 3.64(\mathrm{~d}, 3 \mathrm{H}, J=10.57 \mathrm{~Hz})$, 3.72 (d, 3H, $J=10.57 \mathrm{~Hz}), 3.91$ (brs, NH), 6.57-6.69 $(\mathrm{m}, 3 \mathrm{H}), 7.07-7.15(\mathrm{~m}, 2 \mathrm{H}) ;{ }^{13} \mathrm{C}$ NMR $(75 \mathrm{MHz}$, $\left.\mathrm{CDCl}_{3}\right): \delta 13.62,22.11,25.46,28.58,30.33,31.16$, $50.36,52.08\left(\mathrm{~d}, J_{\mathrm{CP}}=7.15 \mathrm{~Hz}\right), 53.17\left(\mathrm{~d}, J_{\mathrm{CP}}=\right.$ $6.60 \mathrm{~Hz}), 112.83,117.41,128.86,146.98$; MS (ESI): $m / z=322[\mathrm{M}+\mathrm{Na}]^{+}$; Anal. Calcd for $\mathrm{C}_{15} \mathrm{H}_{26} \mathrm{NO}_{3} \mathrm{P}: \mathrm{C}$, 60.18; H, 8.75; N, 4.68. Found: C, 60.27; H, 8.69; N, 4.85 .

\section{3d Dimethyl(pyridin-2-ylamino)(thiophen-2-yl)}

methylphosphonate (table 1, entry 15): White solid, m.p. $145-147^{\circ} \mathrm{C}$; IR (KBr): $3300,1602,1481,1228$, 1054, $1025 \mathrm{~cm}^{-1} ;{ }^{1} \mathrm{H}$ NMR (300 $\left.\mathrm{MHz}, \mathrm{CDCl}_{3}\right): \delta$ $3.62(\mathrm{~d}, 3 \mathrm{H}, J=10.57 \mathrm{~Hz}), 3.71(\mathrm{~s}, 1 \mathrm{H}), 3.76(\mathrm{~d}$, $3 \mathrm{H}, J=10.57 \mathrm{~Hz}$ ), 5.13 (brs, NH), 6.01 (q, 1H), 6.45 $(\mathrm{d}, 1 \mathrm{H}, J=8.31 \mathrm{~Hz}), 6.60\left(\mathrm{q}, 1 \mathrm{H}, J_{12}=3.77 \mathrm{~Hz}\right.$,

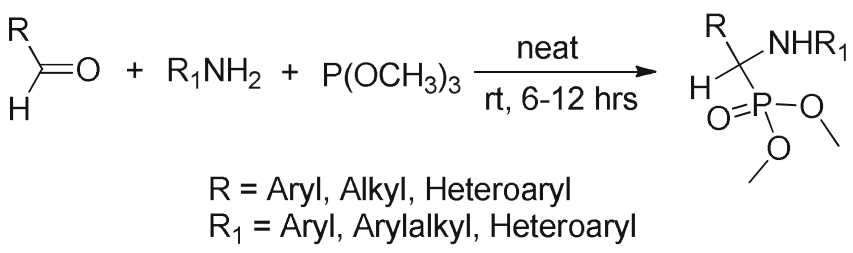

Scheme 1. Eco friendly synthesis of $\alpha$-aminophosphonates. 
Table 1. Synthesis of $\alpha$-aminophosphonates in noncatalytic and solvent free conditions.

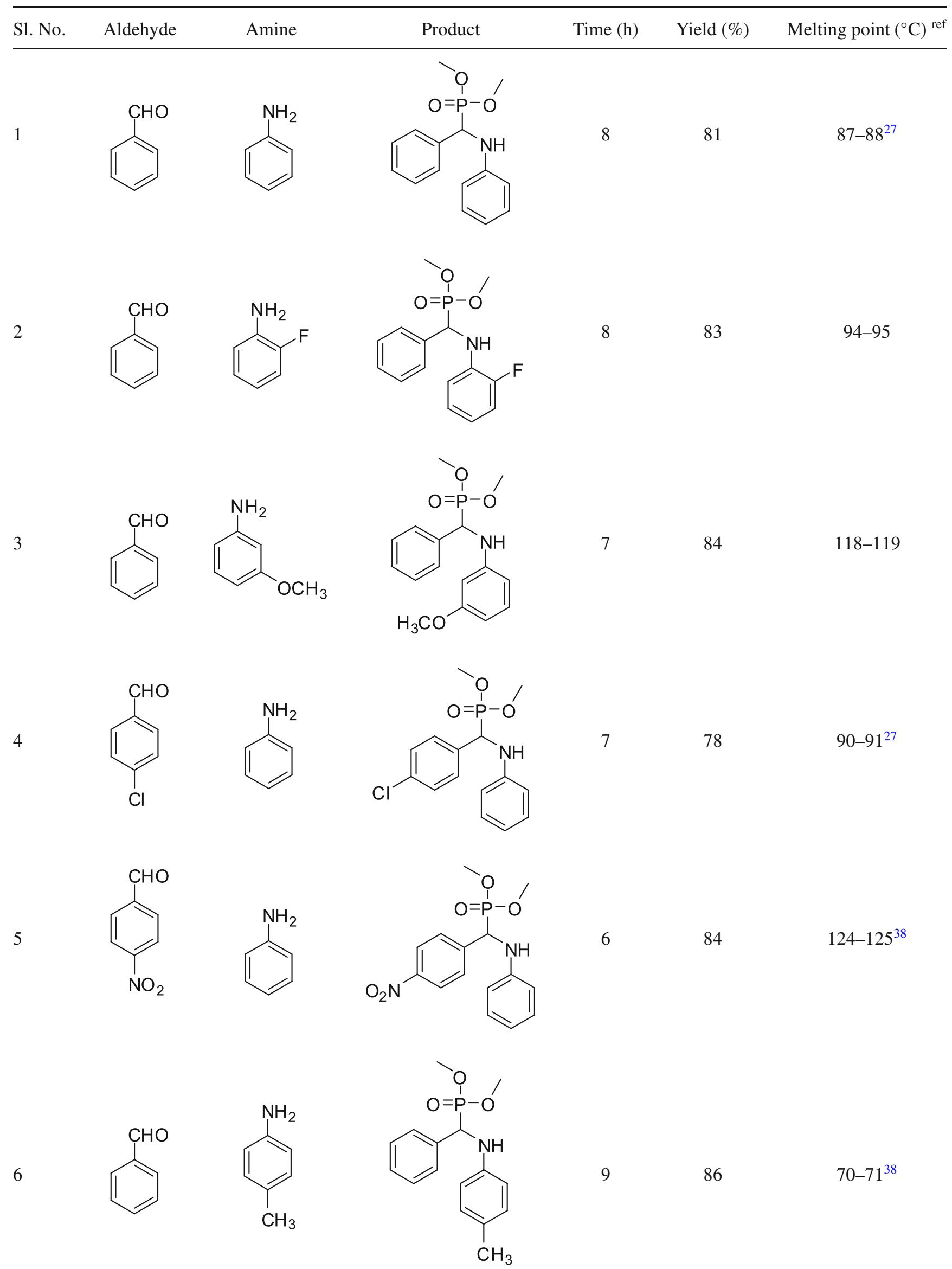


Table 1. (continued).

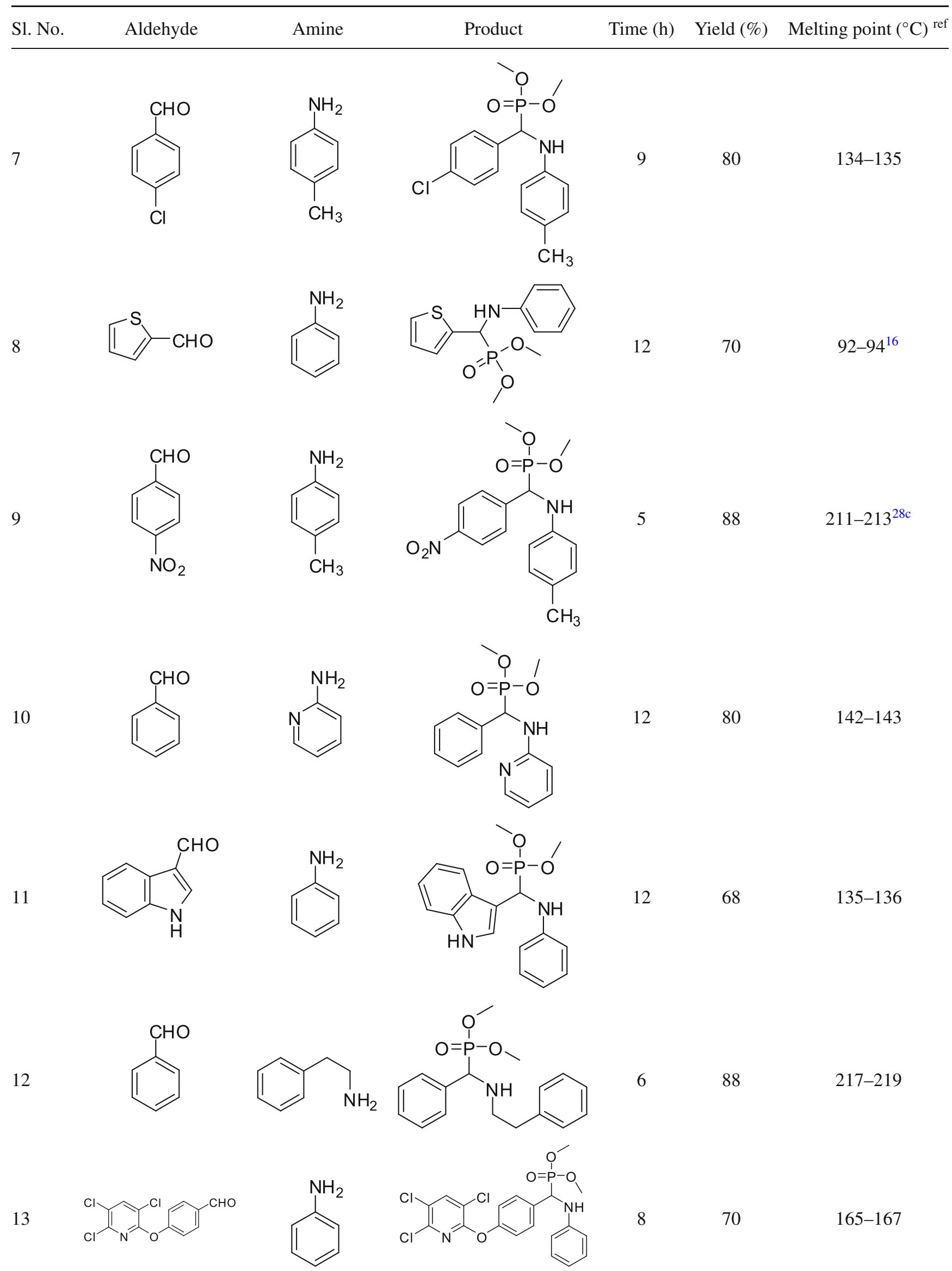


Table 1. (continued).

Sl. No.

$\left.J_{13}=6.04 \mathrm{~Hz}\right), 6.96\left(\mathrm{q}, 1 \mathrm{H}, J_{12}=3.77 \mathrm{~Hz}, J_{13}=\right.$ $5.28 \mathrm{~Hz}), 7.15-7.24(\mathrm{~m}, 1 \mathrm{H}), 7.37(\mathrm{~m}, 1 \mathrm{H}), 8.08(\mathrm{~d}$, $1 \mathrm{H}, J=6.04 \mathrm{~Hz}) ;{ }^{13} \mathrm{C}$ NMR $\left(75 \mathrm{MHz}, \mathrm{CDCl}_{3}\right): \delta$ $45.87,48.01,53.52\left(\mathrm{~d}, J_{\mathrm{CP}}=6.58 \mathrm{~Hz}\right), 53.85\left(\mathrm{~d}, J_{\mathrm{CP}}=\right.$ $6.58 \mathrm{~Hz}), 109.20,114.01,125.05,126.51,126.99$, 137.23, 139.38, 147.70, 156.38; MS (ESI): $m / z=321$ $[\mathrm{M}+\mathrm{Na}]^{+}$; Anal. Calcd for $\mathrm{C}_{12} \mathrm{H}_{15} \mathrm{~N}_{2} \mathrm{O}_{3}$ PS: C, 48.32; H, 5.07; N, 9.39. Found: C, 48.39; H, 5.08; N, 9.47.

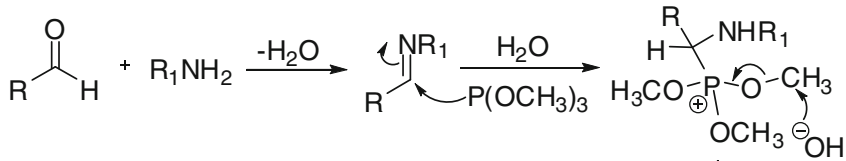

$$
\begin{aligned}
& -\mathrm{CH}_{3} \mathrm{OH}
\end{aligned}
$$

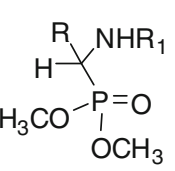

Scheme 2. Plausible mechanism.

\section{Results and discussion}

At the outset, taking the one-pot reaction of benzaldehyde, aniline and trimethyl phosphite (or triethyl phosphite) as a typical example, solvent-free noncatalytic protocol was attempted at ambient temperature. The reaction proceeds smoothly in $8 \mathrm{~h}$ to yield the corresponding $\alpha$-aminophosphonates in $81 \%$ (with trimethyl phosphite) and $84 \%$ (with triethyl phosphite), with an optimum ratio of reactants being 1:1:1.1 (scheme 1).

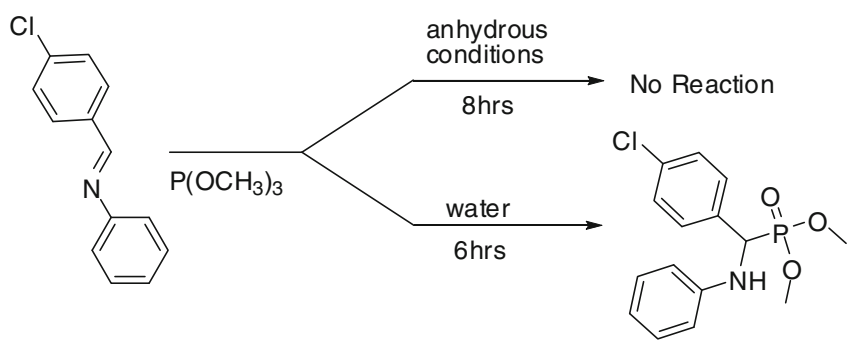

Scheme 3. Synthesis of aminophosphonates from Schiff's base and trimethyl phosphite. 
Table 2. Comparison of product yields in various methods.

\begin{tabular}{lccccccc}
\hline & \multicolumn{2}{c}{ Substrates } & & \multicolumn{3}{c}{ Yield (\%) of $\alpha$-aminophosphonates } \\
\cline { 2 - 3 } \cline { 6 - 7 } S1. No. & Aldehyde & Amine & & $\mathrm{BDMS}^{32}$ & $\mathrm{AlCl}_{3}^{16}$ & $\mathrm{ZrCl}_{4}^{10}$ & No catalyst \\
\hline 1 & Aromatic & Aromatic & & 80 & 80 & 82 & 81 \\
2 & Aromatic & Aliphatic & & 83 & 80 & 85 & 88 \\
3 & Aliphatic & Aromatic & & Trace & Trace & Trace & 71 \\
4 & Aromatic & Aromatic secondary & & Trace & Trace & Trace & 58 \\
\hline
\end{tabular}

To explore the scope of this protocol, we examined various aldehydes, amines as shown in table 1 with trimethyl phosphite. In general, all the reactions with variety of aryl, alkyl and heteroaryl aldehydes and aryl, arylalkyl and heteroaryl amines are clean and the $\alpha$ aminophosphonates were obtained in high yields, under optimized conditions. Another salient feature of this approach is that the reaction proceeds well with the secondary amines also (table 1, entry 17). The electronic effects i.e., electron withdrawing groups on aldehydes (table 1, entry 5 and 9) and electron releasing groups on amines (table 1, entries 6, 7 and 9) increased the rate of reaction and yield of the products. Further, the reaction is also facile for the solid substrates i.e., when the aldehydes and amines involved are solids.

The mechanism of reaction (as shown in scheme 2) involves the nucleophilic addition of trimethyl phosphite on imine (generated in situ from aldehyde and amine) to produce a phosphonium intermediate, which in the presence of water looses methanol to give the desired aminophosphonates.

In order to prove the involvement of water in the reaction mechanism unambiguously, the reaction was performed with pre-synthesized imine, thereby avoiding water generated in situ. As expected, the reaction of the preformed imine with trimethyl phosphite did not proceed under moisture-free conditions where as the addition of water to the reaction medium in stoichiometric amount facilitated the progress in reaction (as shown in scheme 3). Intriguing aspect being that water is detrimental to the stability of trimethyl phosphite but it is the same water does help in completion of the reaction. ${ }^{39}$

A comparative evaluation of the method was done by with respect to other methods reported, such as Lewis acid catalysed and solvent-free protocol as shown in table 2. It was found that the present method takes longer time than others, the yields are comparable. Further, it is found that the method is superior when the aldehyde involved is aliphatic as well as with aromatic secondary amines and when aldehydes and amines involved are both solids.

\section{Conclusion}

A simple, efficient and elegant protocol for the onepot synthesis of $\alpha$-aminophosphonates from variety of aldehydes, amines and trimethyl phosphite in catalystfree and solvent-free conditions at ambient temperature is presnted. The major highlight of the protocol is that it is in total agreement with the green chemistry principles: free of any chemical auxiliaries (solvent, catalyst, etc.) and energy efficient (ambient temperature). This approach for biologically significant compounds is an attractive and useful method fits very well in to the green synthetic procedures, compared to the existing innumerable methodologies. Further, this approach highlights the importance and relevance of water in promoting the reaction for the first time.

\section{Acknowledgements}

We thank the Director, CSIR-IICT and Head, Crop Protection Chemicals Division, for the facilities, encouragement and support. SRM is thankful to the Council of Scientific and Industrial Research (CSIR), New Delhi, India, for the fellowship.

\section{References}

1. (a) Baylis E K, Campbell C D and Dingwall J G 1984 J. Chem. Soc. Perkin. Trans. 1 2845; (b) Atherton F R, Hassal C H and Lambert R W 1986 J. Med. Chem. 29 29; (c) Noyori R 1994 Asymmetric catalysis in organic synthesis, John Wiley and Sons: New York

2. (a) Kafarski P and Lejczak B 2001 Curr. Med. Chem. Anti-Cancer Agents 1 301; (b) Kafarski P and Lejczak B 1991 Phosphorus Sulfur Silicon Relat. Elem. 63 193; (c) Hilderbrand R L 1983 The role of phosphonates in living systems (Boca Raton, FL: CRC); (d) Engel R 1988 Synthesis of carbon-phosphorus bond (Boca Raton, FL: CRC)

3. (a) Allen M C, Fuhrer W, Yuck B, Wade R and Wood J M 1989 J. Med. Chem. 32 1652; (b) Peman A, Stahl W, 
Wagner K, Ruppert D and Budt K H 1994 Bioorg. Med. Chem. Lett. 4 2601; (c) Natchev I A 1988 Liebigs. Ann. Chem. 1988 861; (d) Huang J and Chen R 2000 Heteroatom Chem. 11480

4. Qian C and Huang T 1998 J. Org. Chem. 634125

5. Laschat S and Kunz H 1992 Synthesis 90

6. Ha H-J and Nam G-S 1992 Synth. Commun. 221143

7. Zon J 1981 Pol. J. Chem. 55643

8. Ranu B C, Hajra A and Jana U 1999 Org. Lett. 11141

9. Chandrasekhar S, Prakash S J, Jagadeshwar V and Narsihmulu C 2001 Tetrahedron Lett. 425561

10. Yadav J S, Reddy B V S, Raj K S,Reddy B and Prasad A R 2001 Synthesis 2277

11. Manabe K and Kobayashi S 2000 Chem. Commun. 669

12. (a) Heydari A, Hamadi H and Pourayoubi M 2007 Catal. Commun. 8 1224; (b) Hamadi H, Kooti M, Afshari M, Ghiasifar Z and Adibpour N 2013 J. Mol. Catal. A-Chem. 37325

13. Bhattacharya A K and Kaur T 2007 Synlett 745

14. (a) Bhagat S and Chakraborti A K 2007 J. Org. Chem. 72 1263; (b) Wu J, Sun W, Xia H and Sun X 2006 Org. Biomol. Chem. 41663

15. Kaboudin B and Sorbiun M 2007 Tetrahedron Lett. 48 9015

16. Manjula A, Rao B V and Neelakantan P 2003 Synth. Commun. 332963

17. Tajbakhsh M, Heydari A, Alinezhad H, Ghanei M and Khaksar S 2008 Synthesis 352

18. Akiyama T, Sanada M and Fuchibe K 2003 Synlett 1463

19. Mitragotri S D, Pore D M, Desai U V and Wadgaonkar P P 2008 Catal. Commun. 91822

20. Kumar A S, Taneja S C, Hundal MS and Kapoor K K 2008 Tetrahedron Lett. 492208

21. Hosseini-Sarvari M 2008 Tetrahedron 645459

22. Kaboudin B and Nazari R 2001 Tetrahedron Lett. 42 8211

23. Firouzabadi H and Jafarpour M 2008 J. Iran Chem. Soc. 5159

24. Bhagat S and Chakraborti A K 2008 J. Org. Chem. 73 6029
25. Xu F, Luo Y, Deng M and Shen Q 2003 Eur. J. Org. Chem. 4728

26. (a) Saidi M R and Azizi N 2002 Synlett 1347; (b) Azizi N, Rajabi and Saidi M R 2004 Tetrahedron Lett. 45 9233; (c) Azizi N and Saidi M R 2003 Tetrahedron 59 5329

27. Vahdat S M, Baharfar R, Tajbakhsh M, Heydari A, Baghbanian S M and Khaksar S 2008 Tetrahedron Lett. 496501

28. (a) Akbari J and Heyadri A 2009 Tetrahedron Lett. 50 4236; (b) Fang D, Yang J and Ni C 2011 Heteroatom Chem. 22 5; (c) Zhang X, Qu Y, Fan X, Bores C, Feng D, Andrei G, Snoeck R, Clercq E D and Loiseau P M 2010 Nucleosides Nucleotides Nucleic Acids 29616

29. Rezaei Z, Firouzabadi H, Iranpoor N, Ghaderi A, Jafari M R, Jafari A A and Zare H R 2009 Eur. J. Med. Chem. 444266

30. Maghsoodlou M T, Khorassani S M H, Hazeri N, Rostamizadeh M, Sajadikhah S S, Shahkarami Z and Maleki N 2009 Heteroatom Chem. 20316

31. Shinde P V, Kategaonkar A H, Shingate B B and Shingare M S 2011 Tetrahedron Lett. 522889

32. Kudrimoti S and Bommena V R 2005 Tetrahedron Lett. 461209

33. Karimi-Jaberi Z and Amiri M 2010 Heteroatom Chem. 2196

34. Banik A, Batta S, Bandyopadhyay D and Banik B K 2010 Molecules 158205

35. Maghsoodlou M T, Heydari R, Habibi-Khorassani S M, Hazeri N, Sajadikhah S S, Rostamizadeh M and Lashkari M 2012 Synth. Commun. 42136

36. Ramalingam S and Kumar P 2008 Catal. Lett. 125315

37. Maghsoodlou M T, Habibi-Khorassani S M, Heydari R, Hazeri N, Sajadikhah S S and Rostamizadeh M 2011 Arab. J. Chem. 4481

38. Mu X-J, Lei M-Y, Zou J-P and Zhang W 2006 Tetrahedron Lett. 471125

39. Ranu B C and Hajra A 2002 Green Chem. 4551

40. Lee S, Park J H, Kang J and Lee J K 2001Chem. Commun. 1698 